\title{
ARUS KAS OPERASI, LEVERAGE, SALES GROWTH TERHADAP FINANCIAL DISTRESS
}

\author{
Melsa Aninda Fitri \\ melsaaninda@gmail.com \\ Vaya Juliana Dillak \\ Universitas Telkom
}

Jl. Telekomunikasi No.1, Jl. Terusan Buah Batu - Bojongsoang, Bandung, Jawa Barat 40257

received: 5/8/2020; revised: 8/9/2020; approved: 28/10/2020

\begin{abstract}
The purpose of this study is to determine how the influence of operating cash flow, leverage and sales growth ratios on the occurrence of financial distress. The research method used in this study is a quantitative method. While the data collection techniques used in this study are purposive sampling. The population in this study is the textile and garment subsector companies listed on the Indonesia Stock Exchange in 2015-2018 as many as 14 companies with observational data of 56 samples. This study uses panel data regression analysis techniques. Simultaneous variable operating cash flow, leverage, and sales growth have a significant effect on financial distress. And then, leverage has a significant effect on financial distress. While the operating cash flow and sales growth partially did not have significant effect on financial distress.
\end{abstract}

Keywords: operating cash flow; leverage; sales growth; financial distress; textile and garment subsector

\begin{abstract}
Abstrak
Penelitian ini bertujuan untuk mengetahui pengaruh arus kas operasi, leverage dan sales growth terhadap terjadinya financial distress. Metode penelitian yang digunakan pada penelitian ini yaitu metode kuantitatif dan teknik pengambilan data yang digunakan yaitu teknik purposive sampling. Populasi pada penelitian ini yaitu perusahaan subsektor tekstil dan garmen yang terdaftar di Bursa Efek Indonesia pada tahun 2015-2018 sebanyak 14 perusahaan dengan data observasi sebanyak 56 sampel. Penelitian ini menggunakan teknik analisis regresi data panel. Berdasarkan hasil pengujian secara simultan menyatakan bahwa arus kas operasi, leverage dan sales growth berpengaruh signifikan terhadap terjadinya financial distress. Hasil pengujian secara parsial menyatakan bahwa leverage berpengaruh signifikan terhadap terjadinya financial distress. Sedangkan arus kas operasi dan sales growth secara parsial tidak berpengaruh signifikan terhadap terjadinya financial distress.
\end{abstract}

Kata Kunci: arus kas operasi; leverage; sales growth; financial distress; subsektor tekstil dan garmen 


\section{INTRODUCTION}

Setiap perusahaan memiliki tujuan yaitu memperoleh laba yang optimal (Widhiari dan Merkusiwati, 2015). Sebuah perusahaan diharapkan terus berdiri serta menjalankan berbagai aktivitasnya untuk meraih tujuan perusahaan yang bersangkutan. Stabilitas perusahaan diperlukan untuk mempertahankan perusahaan dan bersaing dengan para kompetitornya. Apabila perusahaan tidak dapat bersaing dan mempertahankan perusahaannya maka perusahaan tersebut dapat memperbesar kemungkinan untuk mengalami kondisi kesulitan keuangan (financial distress) (Wibowo and Musdholifah, 2017).

Salah satu tolok ukur bagi investor untuk berinvestasi pada suatu perusahaan yaitu dengan melihat laba suatu perusahaan. Saat ini perusahaan industri tekstil sedang melemah dikarenakan permintaan yang terus menurun secara global. Selain itu, didukung juga dengan banyaknya impor produk tekstil dan garmen dari luar negeri yang dijual dengan harga yang lebih murah. Sehingga masyarakat lebih memilih untuk membeli produk impor. Akibatnya perusahaan tekstil dan garmen dalam negeri mengalami kesulitan untuk memperoleh laba. Hal ini juga berdampak terhadap rata-rata laba bersih perusahaan industri tekstil yang mengalami kerugian selama empat tahun berturutturut. Beberapa perusahaan yang berpotensi mengalami terjadinya financial distress antara lain PT Argo Pantes Tbk (ARGO), PT Asia Pasific Investama Tbk (MYTX), PT Asia Pasific Fibers Tbk (POLY), dan PT Panasia Indo Resources Tbk (HDTX) (Bosnia, 2018).

Financial distress merupakan kondisi perusahaan dalam keadaan terancam atau tidak sehat, dimana perusahaan mengalami kerugian sehingga perusahaan tidak mampu dalam memenuhi kewajibannya (Yolanda, et. al., 2019). Hal tersebut didukung dengan pernyataan (Putri and Aminah, 2019) yang menyatakan financial distress merupakan kondisi dimana perusahaan mengalami kesulitan keuangan berupa penurunan perolehan laba, ketidakmampuan dalam melunasi hutang serta kewajiban yang disajikan dalam laporan keuangan dengan membandingkan keuangan periode sebelumnya. Indikator kesulitan keuangan dapat dilihat dari analisis aliran kas, strategi perusahaan, dan laporan keuangan perusahaan (Syifa, et. al., 2017).

Proksi yang digunakan untuk mengukur financial distress pada penelitian ini yaitu metode altman z-score. Model Altman Z-score telah dikembangkan pada tahun 1968 oleh Edward Altman di New York University dengan menggunakan Multiple Discriminant Analysis (MDA). Metode ini mengkombinasikan beberapa rasio keuangan. Rumus Altman ini mewakili empat rasio, yaitu likuiditas, profitabilitas, leverage atau solvabilitas, dan kinerja. Seiring berjalannya waktu dan penyesuaian terhadap berbagai jenis industri perusahaan, Altman kemudian melakukan revisi formula z-score agar dapat digunakan pada semua perusahaan, seperti manufaktur, non manufaktur, dan perusahaan penerbit obligasi di negara berkembang. Formula Z-Score modifikasi yang diperoleh adalah (Gama and Geraldes, 2012):

$$
Z "=6,56 X_{1}+3,26 X_{2}+6,72 X_{3}+1,05 X_{4}
$$

Keterangan:

$\mathrm{X}_{1}=$ Working Capital to Total Assets

$\mathrm{X}_{2}=$ Retained Earnings to Total Assets

$\mathrm{X}_{3}=$ Earning Before Interest and T axes to Total Assets $\mathrm{X}_{4}=$ Book Value of Equity to Book Value Total Debt

Klasifikasi perusahaan yang sehat dan bangkrut didasarkan pada nilai Z-Score model Altman Modifikasi, yaitu: jika nilai $\mathrm{Z}<1,1$ maka termasuk perusahaan yang mengalami financial distress. Jika nilai $1,1<Z<2,6$ maka termasuk grey zone (tidak dapat ditentukan apakah perusahaan sehat ataupun mengalami financial distress). Jika nilai $Z>2,6$ maka termasuk perusahaan yang tidak mengalami financial distress.

Menurut Hery (2015), arus kas operasi adalah arus kas yang paling utama dari aktivitas perusahaan. Informasi arus kas dibutuhkan pihak kreditor untuk mengetahui dalam pembayaran utangnya (Santoso, 2017). Apabila arus kas suatu perusahaan jumlahnya besar, maka pihak kreditor mendapatkan keyakinan pengembalian atas kredit yang diberikan.

Leverage merupakan kemampuan suatu entitas untuk melunasi utang jangka pendek maupun utang jangka panjang, atau rasio yang dapat digunakan untuk mengukur sejauh mana suatu entitas dibiayai oleh utang (Wiagustini, 2010). Selain itu leverage merupakan kemampuan perusahaan untuk meningkatkan penggunaan aset yang dibiayai oleh utang yang digunakan untuk meningkatkan pendapatan perusahaan (Restianti and Agustina, 2018). Utang yang terlalu tinggi (extreme leverage) yang dimiliki oleh suatu perusahaan maka dapat mengancam perusahaan mengalami kesulitan untuk memenuhi beban utang serta bunganya (Irving, et. al., 2018).

Debt Ratio dipilih sebagai proksi pada penelitian ini karena pada saat perusahaan berada dalam posisi menuju bangkrut yang salah satunya disebabkan karena besarnya utang, yang memungkinkan untuk menutupi utang yang dimiliki perusahaan adalah aset.

Rasio pertumbuhan penjualan merupakan indikator dari penerimaan pasar atas produk atau jasa yang dihasilkan, yang digunakan untuk mengukur tingkat pertumbuhan penjualan (Simanjuntak, et. al., 2017). Pertumbuhan penjualan yang semakin tinggi menunjukkan berhasilnya suatu perusahaan dalam menjalankan strateginya dalam pemasaran dan penjualan produk (Lubis, 2019). Sales growth merupakan rasio yang berfungsi untuk memprediksi pertumbuhan perusahaan dimasa yang akan datang yang berasal dari 
penerimaan yang dihasilkan atas produk atau jasa, serta pendapatan yang dihasilkan dengan adanya penjualan (Lisiantara and Febrina, 2018).

Penelitian ini dilakukan untuk mengetahui pengaruh Arus Kas Operasi, Leverage, dan Sales Growth terhadap Financial Distress pada perusahaan subsektor tekstil dan garmen yang terdaftar di Bursa Efek Indonesia (BEI) tahun 2015-2018.

\section{METODE}

Metode penelitian yang digunakan yaitu penelitian kuantitatif. Berdasarkan waktu pelaksanaannya, penelitian ini menggunakan data time series dan cross section. Pada penelitian ini teknik pengambilan sampel yang digunakan adalah purposive sampling. Kriteria sampel pada penelitian ini adalah perusahaan subsektor tekstil dan garmen yang terdaftar di Bursa Efek Indonesia pada periode 2015-2018 dan perusahaan subsektor tekstil dan garmen yang konsisten menyajikan laporan keuangan yang telah diaudit di Bursa Efek Indonesia pada periode 2015-2018.

Metode atau teknis analisis yang digunakan untuk menguji hipotesis adalah dengan analisis deskriptif dan analisis regresi data panel. Software yang digunakan untuk melakukan pengujian pada penelitian ini yaitu Eviews Versi 10.

\section{HASIL}

Dilihat dari Tabel 2 hasil pengujian signifikansi random effect model nilai koefisien determinasi yaitu sebesar 0,229850 atau 22,98\%. Hal ini berarti sebesar $22,98 \%$ variabel financial distress perusahaan yang dapat dijelaskan oleh variabel arus kas operasi, leverage, dan sales growth. Sedangkan sisanya sebesar $77,02 \%$ dapat dijelaskan oleh variabel lain.

Berdasarkan Tabel 2 dapat dilihat bahwa nilai probabilitas (f-statistic) nya sebesar 0,000834. Nilai probabilitasnya lebih kecil dibandingkan tingkat signifikansi yaitu sebesar $5 \%$ atau 0,05 , sehingga H0,1 ditolak dan Ha,1 diterima. Kemudian dapat disimpulkan bahwa ada pengaruh secara simultan dari arus kas operasi, leverage, dan sales growth terhadap financial distress. Berdasarkan Tabel 2 dapat dilihat hasil pengujian signifikansi parsial (uji t) sebagai berikut: (1) Nilai probabilitas variabel arus kas operasi yaitu sebesar $0,8766>0,05$, sehingga $\mathrm{H} 0$ diterima yang artinya arus kas operasi tidak memiliki pengaruh signifikan terhadap financial distress. (2) Nilai probabilitas variabel leverage yaitu sebesar $0,0001<0,05$, sehingga $\mathrm{H} 0$ ditolak yang artinya leverage memiliki pengaruh signifikan terhadap financial distress. (3) Nilai probabilitas variabel sales growth yaitu sebesar $0,7632>0,05$, sehingga $\mathrm{H} 0$ diterima yang artinya sales growth tidak memiliki pengaruh signifikan terhadap financial distress.

\section{PEMBAHASAN}

Dilihat dari Tabel 1 hasil pengujian statistik deskriptif menunjukkan bahwa financial distress memiliki nilai mean sebesar -3,010036 yang lebih kecil dibandingkan nilai standar deviasinya sebesar 17,12596. Maka dapat disimpulkan bahwa data financial distress pada penelitian ini bersifat heterogen atau cenderung tidak berkelompok. Variabel financial distress memiliki nilai minimum sebesar $-62,28060$ pada tahun 2016, sedangkan nilai maksimum sebesar 15,99219 pada tahun 2018.

Arus kas operasi memiliki nilai mean sebesar 0,185696 yang lebih kecil dibandingkan nilai standar deviasinya sebesar 0,414163 . Maka dapat disimpulkan bahwa data arus kas operasi pada penelitian ini bersifat heterogen atau cenderung tidak berkelompok. Variabel arus kas operasi memiliki nilai minimum sebesar $-0,34874$ pada tahun 2016, sedangkan nilai maksimum sebesar 2,283252 pada tahun 2018.

Leverage memiliki nilai sebesar 0,945614 yang lebih kecil dibandingkan nilai standar deviasinya sebesar 1,199104. Maka dapat disimpulkan bahwa data leverage pada penelitian ini bersifat heterogen atau cenderung tidak berkelompok. Variabel leverage memiliki nilai minimum sebesar 0,084951 pada tahun 2018, sedangkan nilai maksimum sebesar 5,073297 pada tahun 2017.

Sales growth memiliki nilai mean sebesar 0,042153 yang lebih kecil dibandingkan nilai standar deviasinya sebesar 0,297012. Maka dapat disimpulkan bahwa data sales growth pada penelitian ini bersifat heterogen atau cenderung tidak berkelompok. Variabel sales growth memiliki nilai minimum sebesar $-0,59164$ pada tahun 2018, sedangkan nilai maksimum sebesar 1,527793 pada tahun 2015 .

Nilai probabilitas variabel arus kas operasi lebih besar dari 0,05 , sehingga Ha ditolak dan $\mathrm{H} 0$ diterima yang artinya arus kas operasi tidak memiliki pengaruh signifikan terhadap financial distress. Hal ini menunjukkan semakin tinggi atau rendahnya nilai arus kas operasi tidak memiliki pengaruh terhadap perusahaan mengalami keadaan financial distress. Perusahaan yang memiliki tingkat arus kas operasi yang tinggi beresiko mengalami keadaan financial distress jika perusahaan tidak mampu meningkatkan kegiatan operasionalnya seperti melunasi pinjaman kepada kreditor. Sebaliknya perusahaan yang memiliki tingkat arus kas operasi yang tinggi dapat terhindar dari keadaan financial distress jika perusahaan dapat mengelola arus kas operasi untuk kegiatan operasionalnya dan mampu memenuhi kewajiban jangka pendek yang dimiliki oleh perusahaan. Arus kas operasi tidak berpengaruh terhadap perusahaan mengalami keadaan financial distress karena perusahaan yang memiliki tingkat arus kas operasi yang tinggi belum dapat memberikan gambaran bahwa perusahaan mampu meningkatkan kegiatan operasionalnya seperti melunasi pinjaman kepada kreditor sehingga tidak 
berpengaruh menurunkan resiko perusahaan mengalami kondisi financial distress (Vitarianjani, 2015).

Nilai probabilitas variabel leverage lebih kecil dari 0,05 , sehingga $\mathrm{H} 0$ ditolak dan Ha diterima yang artinya leverage memiliki pengaruh negatif signifikan terhadap financial distress. Hasil penelitian ini bertentangan dengan hipotesis yang telah dibuat yaitu leverage berpengaruh positif signifikan terhadap financial distress. Hal ini dapat diartikan semakin tingginya nilai leverage maka semakin rendah kemungkinan perusahaan mengalami keadaan financial distress. Sebaliknya, semakin rendahnya nilai leverage maka semakin tinggi kemungkinan perusahaan mengalami keadaan financial distress. Perusahaan yang memiliki nilai leverage tinggi tidak selalu memiliki kemungkinan besar terjadinya financial distress, tetapi juga berpeluang untuk terhindar dari terjadinya financial distress. Hal ini terjadi karena perusahaan yang memiliki tingkat utang yang tinggi dapat mengelola utangnya dengan baik sehingga dapat memenuhi untuk pembelian aset dan meningkatkan laba perusahaan (Septiani and Dana, 2019). Selain itu, jika perusahaan memiliki nilai leverage yang tinggi, tetapi perusahaan menggunakan utang tersebut untuk kegiatan operasionalnya seperti membayar beban-beban perusahaan, membeli aset, dan membayar utang yang telah jatuh tempo maka perusahaan dapat terhindar dari terjadinya keadaan financial distress.

Nilai probabilitas variabel sales growth lebih besar dari 0,05 , sehingga Ha ditolak dan $\mathrm{H} 0$ diterima yang artinya sales growth tidak memiliki pengaruh signifikan terhadap financial distress. Hal ini menunjukkan semakin tinggi atau rendahnya nilai sales growth tidak memiliki pengaruh terhadap perusahaan mengalami financial distress. Rasio ini tidak dapat dijadikan sebagai acuan utama untuk mengukur suatu perusahaan mengalami financial distress atau tidak. Hal ini disebabkan karena perusahaan yang mengalami penurunan penjualan maka tidak akan berdampak langsung terhadap perusahaan mengalami kebangkrutan tetapi berpengaruh terhadap penurunan laba dan selama penurunan laba penjualan tidak melebihi batas (margin of safety) yang telah ditetapkan oleh perusahaan, maka tidak akan berpengaruh terhadap terjadinya financial distress (Liana and Sutrisno, 2014). Dan semakin tingginya tingkat penjualan maka perusahaan akan memperoleh laba yang besar pula. Hal ini menggambarkan bahwa perusahaan mampu menjalankan strategi pemasaran dan penjualan produk.

\section{KESIMPULAN}

Berdasarkan pengujian hipotesis secara simultan (uji F), maka dapat diperoleh bahwa arus kas operasi, leverage, dan sales growth secara bersama-sama memiliki pengaruh terhadap terjadinya financial distress pada perusahaan subsektor tekstil dan garmen yang terdaftar di Bursa Efek Indonesia selama periode 2015-
2018. Sedangkan pengujian hipotesis secara parsial (uji t) maka dapat diperoleh bahwa leverage memiliki pengaruh terhadap terjadinya financial distress. Arus kas operasi dan sales growth tidak memiliki pengaruh terhadap terjadinya financial distress pada perusahaan subsektor tekstil dan garmen yang terdaftar di Bursa Efek Indonesia selama periode 2015-2018.

\section{DAFTAR PUSTAKA}

Bosnia, T., 2018. Pendapatan Anjlok 21,48\%, Rugi HDTX Membengkak Jadi Rp 635 M [www. Document].

Fahmi, I., 2014. Analisis Laporan Keuangan. Alfabeta, Bandung.

Gama, A.P.M., Geraldes, H.S.A., 2012. Credit risk assessment and the impact of the New Basel Capital Accord on small and medium-sized enterprises: An empirical analysis. Manag. Res. Rev. 35, 727-749.

Hery. 2015. Analisis Kinerja Manajemen. PT Grafindo, Jakarta.

Irving, S., Purba, M., Muslih, M., 2018. Pengaruh Kepemilikan Institusional, Intellectual Capital, dan Leverage Terhadap Financial Distress (Studi Kasus pada Perusahaan Manufaktur yang Terdaftar di Bursa Efek Indonesia Tahun 2014-2017). J. Account. Financ. 2, 27-40.

Kasmir, 2017. Analisis Laporan Keuangan. PT Raja Grafindo, Jakarta.

Liana, D., Sutrisno, 2014. Analisis Rasio Keuangan Untuk Memprediksi Kondisi Financial Distress Perusahaan Manufaktur Yang Terdaftar di Bursa Efek Jakarta. J. Stud. Manaj. dan Bisnis 1, 1-27.

Lisiantara, G.A., Febrina, L., 2018. Likuiditas, Leverage, Operating Capacity, Profitabilitas, Sales Growth Sebagai Preditor Financial Distress ( Studi Empiris Pada Perusahaan Manufaktur Yang Terdaftar Di Bursa Efek Indonesia Tahun 2013-2016 ). Pros. SENDI 978-979.

Lubis, N.H. dan D.P., 2019. Pengaruh Activity Ratio, Leverage, dan Firm Growth terhadap Financial Distress (Studi Empiris pada Perusahaan Manufaktur yang Terdaftar di BEI periode 2013-2017). J. Kaji. Manaj. dan Wirausaha 01, 173-182.

Putri, G.W., Aminah, W., 2019. Faktor-Faktor Yang Memitigasi Financial Distress pada Perusahaan Pertambangan. J. Ris. Akunt. Kontemporer 11, 1-8.

Restianti, T., Agustina, L., 2018. The Effect of Financial Ratios on Financial Distress Conditions in Sub Industrial Sector Company. Account. Anal. J. 7, 25-33.

Santoso, S.I., 2017. Pengaruh Laba, Arus Kas dan Corporate Governance terhadap Financial Distress. J. Al-Buhuts 13, 1-22.

Septiani, N.M.I., Dana, I.M., 2019. Pengaruh Likuiditas, Leverage, Dan Kepemilikan Institusional Terhadap Financial Distress Pada Perusahaan Property Dan Real Estate. E-Jurnal Manaj. Univ. Udayana 8, 3110. 
Simanjuntak, C., Titik, F., Aminah, W., 2017. Pengaruh Rasio Keuangan Terhadap Financial Distress ( Studi Pada Perusahaan Transportasi Yang Terdaftar Di Bursa Efek Indonesia. e- Proceeding Manag. 4, 1580-1587.

Syifa, H.M., Kristanti, F.T., Dillak, V.J., 2017. Financial Distress, Kepemilikan Institusional, Profitabilitas Terhadap Konservatisme Akuntansi. Jrak 9, 1.

Vitarianjani, N., 2015. Prediksi Kondisi Financial Distress dan Faktor yang Mempengaruhi. J. Ilm. Mhs. Fak. Ekon. Univ. Jember.

Wiagustini, N.L.P., 2010. Dasar-Dasar Manajemen Keuangan. Udayana University Press, Denpasar.

Wibowo, W., Musdholifah, 2017. Pengaruh Corporate
Governance, Kinerja Keuangan dan Ukuran Perusahaan Terhadap Financial Distress pada Sektor Pertambangan Indonesia. J. Ilmu Manaj. $5,1-13$.

Widhiari, N., Merkusiwati, A., 2015. Pengaruh Rasio Likuiditas, Leverage, Operating Capacity, Dan Sales Growth Terhadap Financial Distress. E-Jurnal Akunt. 11, 456-469.

Yolanda, M., Hapsari, K.W., Akbar, S.N., Herawaty, V., 2019. Pengaruh kepemilikan manajerial dan kualitas audit terhadap earning management dengan financial distress sebagai variabel intervening (studi empiris pada perusahaan manufaktur yang terdaftar di bei 2015-2017). Akuntansi 1-8.

Tabel 1. Hasil Uji Statistik Deskriptif

\begin{tabular}{lcccc}
\hline & FD & OCF & DAR & SG \\
\hline Mean & -3.010036 & 0.185696 & 0.945614 & 0.042153 \\
Median & 1.820688 & 0.102801 & 0.630264 & 0.065296 \\
Maximum & 15.99219 & 2.283252 & 5.073297 & 1.527793 \\
Minimum & -62.28060 & -0.348738 & 0.084951 & -0.591636 \\
Std. Dev. & 17.12596 & 0.414163 & 1.199104 & 0.297012 \\
\hline
\end{tabular}

Sumber: Data yang telah diolah,2020

Tabel 2. Hasil Pengujian Signifikansi Random Effect Model

\begin{tabular}{|c|c|c|c|c|}
\hline \multicolumn{5}{|l|}{ Dependent Variable: Y } \\
\hline \multicolumn{5}{|c|}{ Method: Panel EGLS (Cross-section random effects) } \\
\hline \multicolumn{5}{|c|}{ Date: $03 / 19 / 20$ Time: $14: 31$} \\
\hline \multicolumn{5}{|c|}{ Sample: 20152018} \\
\hline \multicolumn{5}{|l|}{ Periods included: 4} \\
\hline \multicolumn{5}{|c|}{ Cross-sections included: 14} \\
\hline \multicolumn{5}{|c|}{ Total panel (balanced) observations: 56} \\
\hline \multicolumn{5}{|c|}{ Swamy and Arora estimator of component variances } \\
\hline Variable & Coefficient & Std. Error & t-Statistic & Prob. \\
\hline $\mathrm{C}$ & 3.696984 & 0.614397 & 6.017258 & 0.0000 \\
\hline $\mathrm{OCF}$ & -0.033312 & 0.213396 & -0.156103 & 0.8766 \\
\hline DAR & -1.952969 & 0.444243 & -4.396175 & 0.0001 \\
\hline SG & 0.046203 & 0.152537 & 0.302894 & 0.7632 \\
\hline \multicolumn{5}{|c|}{ Effects Specification } \\
\hline & & & S.D. & Rho \\
\hline \multicolumn{3}{|l|}{ Cross-section random } & 0.794978 & 0.9282 \\
\hline \multicolumn{3}{|l|}{ Idiosyncratic random } & 0.221151 & 0.0718 \\
\hline \multicolumn{5}{|c|}{ Weighted Statistics } \\
\hline R-squared & 0.271858 & \multicolumn{2}{|c|}{ Mean dependent var } & 0.202669 \\
\hline Adjusted R-squared & 0.229850 & \multicolumn{2}{|c|}{ S.D. dependent var } & 0.253653 \\
\hline S.E. of regression & 0.222601 & \multicolumn{2}{|c|}{ Sum squared resid } & 2.576663 \\
\hline F-statistic & 6.471556 & \multicolumn{2}{|c|}{ Durbin-Watson stat } & 1.080972 \\
\hline Prob(F-statistic) & 0.000834 & & & \\
\hline \multicolumn{5}{|c|}{ Unweighted Statistics } \\
\hline R-squared & 0.463763 & Mean deper & dent var & 1.471105 \\
\hline Sum squared resid & 37.07317 & Durbin-Wat & on stat & 0.075130 \\
\hline
\end{tabular}

Sumber: Data yang telah diolah,2020 